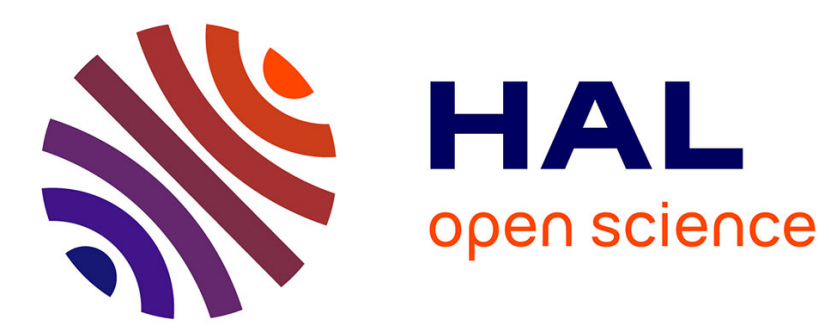

\title{
Mapping Modes of Rural Labour Migration in China Sylvie Démurger
}

\section{To cite this version:}

Sylvie Démurger. Mapping Modes of Rural Labour Migration in China. 2012. halshs-00695632

\section{HAL Id: halshs-00695632 \\ https://shs.hal.science/halshs-00695632}

Preprint submitted on 9 May 2012

HAL is a multi-disciplinary open access archive for the deposit and dissemination of scientific research documents, whether they are published or not. The documents may come from teaching and research institutions in France or abroad, or from public or private research centers.
L'archive ouverte pluridisciplinaire HAL, est destinée au dépôt et à la diffusion de documents scientifiques de niveau recherche, publiés ou non, émanant des établissements d'enseignement et de recherche français ou étrangers, des laboratoires publics ou privés. 


\section{W P 1209}

Mapping Modes of Rural Labour Migration in China

Sylvie Démurger

Mai 2012 


\section{GATE Groupe d'Analyse et de Théorie Économique Lyon-St Étienne}

93, chemin des Mouilles 69130 Ecully - France

Tel. +33(0)4 72866060

Fax $+33(0) 472866090$

6, rue Basse des Rives 42023 Saint-Etienne cedex 02 - France

Tel. +33 (0)4 77421960

Fax. +33 (0)4 77421950

Messagerie électronique / Email : gate@gate.cnrs.fr

Téléchargement / Download : http://www.gate.cnrs.fr - Publications / Working Papers 


\title{
Mapping Modes of Rural Labour Migration in China
}

\author{
Sylvie Démurger \\ Université de Lyon, Lyon, F-69007, France \\ CNRS, GATE Lyon St Etienne, 93 chemin des Mouilles, Ecully, F-69130, France \\ E-mail: demurger@gate.cnrs.fr
}

This version: May 5, 2012

Paper prepared for the China Update 2012, ed. by Ligang Song and Huw McKay

\begin{abstract}
:
Internal labour migration has become an important part of the process of China's industrialization and urbanisation in the 2000s. Using micro data for the year 2007, this chapter attempts to contribute to a better understanding of the motives of and the constraints to labour mobility in China. Drawing on various empirical investigations at the household level, it examines both the decision and the level of migration and provides a mapping of the main factors driving different types of labour mobility across space (by destination) and time (by duration).
\end{abstract}

Keywords: rural-urban migration, destination, duration, migration networks, China.

JEL Classification: O15, R23, D13, O53. 


\section{Introduction}

China's rapid economic development and government policy changes towards higher interregional labour mobility have encouraged a massive rural-urban labour force exodus since the mid-1980s. The National Bureau of Statistics of China estimated the total number of rural migrants working in cities in 2011 at about 158 million $^{1}$. Compared to developed countries where similar population movements occurred in the nineteenth and the twentieth centuries, the much larger scale and pace of population movements in China confront the Chinese authorities with extremely challenging policy issues that call for a better understanding of the motives of and the constraints to labour mobility in China.

Rural-to-urban migration has become a norm for rural households in China. In 2007, about one-half of the rural households had at least one member working outside the village. As part of their diversification strategy, migration is one of the main sources of income for rural households, with remittances accounting for about 21 per cent of total rural income and 43 per cent of migrant-sending households' total income in 2007 (Démurger and Li 2012). Multiple sources of incentives can motivate households and individuals to migrate. The economic literature on the determinants of migration usually highlights two sets of factors: the "pull” and the "push" factors (Barrett et al. 2001). Since Todaro (1969), the expected urban-rural income gap is considered as the most important pull factor for the migration decision. On the other hand, push factors typically include ex ante risk management, ex post risk coping, or response to a surplus of rural labour driven by land constraints and population pressure.

From a theoretical perspective, the seminal works of Oded Stark (e.g. Stark 1991) and the "New Economics of Labour Migration” (NELM) literature have revitalized interest in the motives and the consequences of migration in developing countries. The general framework proposed by the New Economics of Labour Migration departs from the neoclassical approach to migration in two ways (Taylor 1999). First, it considers the household, rather than the individual, as the most appropriate decision-making unit. By integrating migration decisions into a household strategy, individual income maximization is no longer the only motive for migration and income risk minimization can be specifically considered. Second, it accounts

\footnotetext{
${ }^{1}$ Source: http://www.stats.gov.cn/tjfx/fxbg/t20120427_402801903.htm. This number refers to the rural labour force that has migrated for work out of their township of residential registration for at least 6 months in the year of investigation.
} 
for the imperfection of markets other than the labour market in explaining migration behaviours.

The existing empirical research on the motivations for labour migration in China has documented that both rural labour surplus and the rural-urban income gap are major driving forces of migration decisions (Zhao 1999; Zhu 2002; Zhao 2005). Using a village survey conducted in 1996, Rozelle et al. (1999) also showed that the poorest households were often not capable of participating in migrant labour markets. In addition, land size and land tenure insecurity both reduce migration (Mullan et al. 2011). At the individual level, age, gender and marital status have been consistently found to play a significant role in migration decisions (Hare 1999; Zhao 1999), whereas evidence on the role of education is mixed. Finally, drawing on a sample of 824 households surveyed in 6 provinces in 1999, Zhao (2003) pointed out the role of migrant networks in labour migration, in particular through practical assistance provided in the process of migration. Chen et al. (2010) confirmed the role of social interactions in job-related migration based on data from the 2006 China agricultural census. They found evidence of the effect being mostly driven by co-villagers helping each other to reduce moving costs and find job opportunities at destination.

Using household-level data from the Rural Household Survey of the China National Bureau of Statistics for the year 2007, this chapter updates the existing empirical literature on the determinants of migration by differentiating various modes of migration and by extending the analysis of the role of family and community networks. Following the "New Economics of Labour Migration”, we use the household as the unit of analysis. Our focus is on understanding several aspects of the migration decision and migration size by analysing the determinants of migration, of migration destination and of migration duration. In particular, we aim at mapping out different types of migration across space (namely short-distance versus long-distance migration) and time (short-term versus long-term migration). Drawing on various estimations, we argue that the various types of migration are driven by different factors. Moreover, in addition to household characteristics and assets and to geographic attributes, we account for the specific impact of family and community networks.

The following research questions are successively examined: (a) What determines the participation of Chinese rural households in migration? (b) What determines their destination choice and the time spent in migration? (c) What determines the size of migration? We explore these issues by estimating bivariate probit and Poisson models that include a number of relevant characteristics of the family and community situation and background on household-level data for the year 2007. 
The chapter is structured as follows. Section 2 presents the methodological framework used for the empirical analysis of the determinants of migration. The data are briefly discussed in Section 3 and the econometric results are presented in the next two sections. Section 4 is devoted to a discussion of the determinants of household migration decision, by destination and duration. Section 5 extends the analysis to the size of migration, measured through the number of household members sent to migration. Section 6 concludes.

\section{Methodological framework}

We examine the household-level migration decision using multivariate analysis. We proceed in two steps and successively examine the decision to migrate (including the choice of destination and the duration of migration) and the size of migration.

The framework for estimating the determinants of the migration decision is as follows. The household decision to engage in migration is postulated to reflect its underlying (unobserved) utility:

$$
y_{i}^{*}=Z_{i} \beta+\varepsilon_{i}
$$

where $\varepsilon_{i}$ is assumed to be independent from $Z_{i}$ and to have a standard normal distribution (probit model). The actual decision to send a migrant is given by the following:

$$
y_{i}=\left\{\begin{array}{l}
1 \text { if } y_{i}^{*}>0 \\
0 \text { otherwise }
\end{array}\right.
$$

In the model above, $Z$ is a vector of household demographics and assets and of village attributes that are supposedly influencing migration decision, destination and duration. Drawing on the theoretical literature on the determinants of the migration decision, it includes the following variables.

First, households demographics and assets are captured by the household size, the share of male adults, the number of old dependents, the number of children below the age of 16 , the age and education level of the household head ${ }^{2}$, and the household land size per capita. In the vein of the push and pull factors detailed above, most household-level variables refer to the coping capacity of households facing risks or to their risk exposure. Typically, household size and composition together with the household's land assets account for potential diminishing labour returns in the presence of land constraints.

\footnotetext{
${ }^{2}$ As argued by Mullan et al. (2011), education can be used as a proxy for off-farm wages that should ideally be introduced as determinants of the migration decision, but are not available.
} 
Beyond specific household characteristics, migration networks can also be important drivers of the migration decision, as they may serve as cost reducing devices. A body of theoretical and empirical literature has highlighted the role of information networks in lowering the cost of migration through information on employment opportunities at destination, better access to employment at destination and as a source of help to settle down at destination (Taylor 1986; Winters et al. 2001; Görlich and Trebesch 2008; Haug 2008). In their study of the role of migrant networks in Mexico, Winters et al. (2001) further distinguish the differentiated role of family and of community networks, the former being identified as "strong ties" networks while the latter are defined as "weak ties" networks. They find that both family and community networks lower the cost of migration and that they are substitutes: once migration is well established in a community, family networks become less important. Moreover, once migration networks are established, they are also more important than household characteristics in explaining migration patterns. To investigate the role of migration networks, we follow Winters et al. (2001) and define two different indicators: 1) a community-level network: the village population share of migrants in 2005; and 2) a familylevel network: whether the household has more than one member with a migration experience. This second variable includes both on-going migrants and return migrants, and thus measures the accumulated experience of migration at the household level.

Finally, we account for location attributes by including dummies for villages located in a central or a western province. We also employ village level information on access to an asphalt road to account for proximity to market.

Besides migration decision, we also explore the determinants of destination and duration probability. For that, we employ a recursive model to account for unobservable characteristics such as motivation or risk aversion that may simultaneously determine the migration decision and the destination/duration decision. If unobservable heterogeneity has a direct influence on both decisions (to migrate as well as how far or how long to migrate) then the migration destination/duration variable will be correlated with the error term $\varepsilon_{i}$, which will make it effectively endogenous in the selected sample. As suggested by Greene (2008), this unobservable heterogeneity can be captured by using a recursive bivariate Probit model, which estimates the migration duration/destination choice together with migration decision. The system of equations is identified by nonlinearities even if the vectors of observables overlap completely.

Finally, to examine the determinants of the level of migration, we use a Poisson model of the number of migrants in a household, classified by destination and duration. A model 
similar to the above migration decision model is estimated with key independent variables including household demographics and assets, migration networks and community characteristics.

\section{Data and stylized facts}

We use data from the Rural Household Survey carried out by the National Bureau of Statistics under the Rural-Urban Migration in China (RUMiC) project ${ }^{3}$ in 2008. The survey covers 8,000 rural households in nine provinces (Hebei, Jiangsu, Zhejiang, Anhui, Henan, Hubei, Guangdong, Chongqing and Sichuan).

We identify migrants as household members who work outside their home village and have been living away for at least 6 months. This rather broad definition includes individuals who work off the farm in the neighbourhood of their home village (e.g. county seat), which will allow us to differentiate migrants according to the distance to their home village. With this definition, 48 per cent of the 8,000 surveyed households had at least one migrant member in 2007 and migrant-sending households had on average 1.7 migrant members. The survey provides additional information on migration destination and duration that are also useful here.

Concerning destination, the records include the location of employment for working household members, which allows us to categorize migrants through the distance of their working destination to their home village as follows: working in the local county seat / working in a city or another county within the province / working in a city or a county outside the province. In 2007, 19 per cent of the sending households had at least one migrant member working in the local county seat, 30 per cent had at least one migrant member working outside the county within the province and 44 per cent had at least one migrant member working outside the province. As far as the level of migration is concerned, Table 1 shows that migrant-sending households have on average 0.70 members working in the local county seat, 0.46 members working within the province and 0.26 members working in another province. By comparison with the shares of sending households by destination, these figures indicate that the number of migrants is inversely proportional to the share of sending households by distance. Hence, while sending households actively participate in "longdistance” migration (with a share of 44 per cent), they send few members far away. In

\footnotetext{
${ }^{3}$ For details about the whole project and the survey design and implementation, see Meng et al. (2010). See also http://cbe.anu.edu.au/schools/eco/rumici/ for a map of the surveyed provinces and for survey questionnaires.
} 
contrast, sending households marginally contribute to "short-distance" migration (with a share of 19 per cent), but households involved in "local” migration send more members locally.

Concerning duration, we separate "short-run" migrants, whose maximum migration duration in 2007 was less than 7 years and "long-run migrants" otherwise ${ }^{4}$. The overwhelming proportion of migrant-sending households (60 per cent) have at least one migrant member working outside the village for less than 7 years, but summary statistics also indicate that 44 per cent have at least one migrant member outside the village for more than 7 years. Numbers indicating the size of migration by duration confirm the higher incidence of short-run migration: migrant-sending households send on average 0.89 members for less than 7 years and 0.61 members for 7 years or more.

To sum up, the above statistics highlight some key stylized facts about migration. They confirm the high incidence of rural migration in China as well as its temporary, or at least short-run, nature. Interestingly, they also point to migration patterns involving both longdistance and short-distance movements.

\section{$<$ Insert Table 1>}

Table 1 also contains baseline characteristics of migrant sending and non-sending households for the key variables used in the empirical analysis. There is a clear gap in household characteristics between the two groups, as indicated by mean tests significant for almost all variables. Sending households are significantly larger and have a higher share of adult males: the average migrant-sending household size is 4.4 persons (against 3.5 for nonsending households), with 52 percent of adult males. In terms of age composition, they have fewer elderly members ( 0.15 on average, against 0.2 for non-sending households), but more children below the age of 16 ( 0.7 on average, against 0.64 for non-sending households). With regard to household assets, an interesting feature is that the average land endowment per person is significantly lower for sending households who have an average of $1.24 \mathrm{mu}$ (or 0.08 hectares) per capita, as compared to $1.46 \mathrm{mu}$ (or 0.10 hectares) per capita for non-sending households. This significant difference may reflect both land shortages and labour surplus in migrant-sending households, a dimension that will be further explored in Section 4. In contrast, summary statistics on household human capital show no significant difference between sending and non-sending households: the average age of the household head is

\footnotetext{
${ }^{4}$ One should note that the design of the question does not allow us to distinguish different individual sojourns that could have been interrupted by a temporary return. As a consequence, the duration calculated here is a maximum for each individual.
} 
slightly above 50 years and the education level of the household head is about 7.2 years of schooling. That is 2 years below the 9-year compulsory education system.

As for migration networks, the data show that 53.7 per cent of migrant-sending households have a family migration experience, whereas the share is only 8.6 per cent for non-sending households. At the village level, sending households also have a significantly larger village network than non-sending households. Finally, geographic characteristics also exhibit significant differences between migrant sending and non-sending households. Not surprisingly, the incidence of migrant sending households is significantly higher in both central and western provinces, which are emigration provinces compared to coastal provinces. Interestingly, access to asphalt road is significantly higher for non-sending households than for sending households.

\section{The migration decision}

Table 2 presents marginal effects (at mean values) from the estimation of a simple probit model for whether households have any migrant member (column 1) and of recursive bivariate probit models for the choice of destination and duration (columns 2 to 6 ) that allow for selection on unobservable characteristics ${ }^{5}$.

\section{$<$ Insert Table 2>}

On the migration decision model (column 1), we observe that the likelihood of sending a migrant increases with household size and male labour force, whereas it decreases with the number of old dependents and of children below the age of 16. This is consistent with the empirical literature showing that migration is associated with larger households and larger male labour force, both factors that reduce the opportunity cost for the family to send a migrant to cities ${ }^{6}$. In contrast, a higher dependency ratio of the household (through both elderly and children) significantly reduces family labour availability for migration. Moreover, we find that older households have a lower probability to participate in migration: older household heads may be more reluctant to send family members to cities most probably because of a higher risk aversion with old age. Among other reasons, the lack of access to health care services outside the home province may also influence the reluctance of older

\footnotetext{
${ }^{5}$ For space constraint, columns (2) to (6) only report the destination/duration equation of the recursive bivariate probit model. The full model includes the migration decision equation. Since this equation is estimated separately as a first step (column (1)) and since the estimates are stable across specifications, we do not report the migration decision estimate for the recursive bivariate probit models.

${ }^{6}$ See e.g. Dercon and Krishnan (1996) on Ethiopa and Tanzania, Winters et al. (2001) on Mexico, or Zhao (2003) on China.
} 
household heads. As a measure of the demand for farm labour, the per capita size of land is unsurprisingly found to have a negative and significant impact on the probability of a household to send migrants. In the specific case of China, it may also reflect the need for households to keep farming their land if they want to protect their land use rights ${ }^{7}$ (Mullan et al. 2011). Once the labour force size is controlled, only families with smaller landholdings can afford to send household members to migrate.

The importance of both family and village network effects in the household migration decision is also highlighted in column (1). Having more than one member with migration experience strongly increases the household's probability of sending a migrant: the probability is increased by 43.3 percent compared to households with no migration experience. Likewise, a one percent increase in the village share of migrants increases the household's migration probability by 72 percent. Hence, both family and community networks seem to facilitate migration and their marginal effect is important. In contrast, after controlling for location in emigration provinces, the ease of access to markets, as proxied by the asphalt road dummy, is not found to significantly influence migration decisions. For households living in villages with an easier access to the market, migration may not be the most attractive option since there may be other, local, opportunities to diversify.

Columns (2) to (4) show estimates for a specific destination: another province, any city in the same province, or the local county seat. A comparison of the three estimations reveals interesting differences as well as similarities. Household size has a significant and positive effect on all migration destinations. Interestingly, the marginal effect is three times larger for long-distance migration as compared to local migration. Likewise, the adult gender composition of the household significantly (and positively) influences the probability to send a migrant to a city in another county or another province, whereas the estimated impact is non-significant on local labour mobility. In contrast, the presence of old and young dependents significantly lowers the probability of sending migrants to any destination, and again, the marginal impact seems stronger for long-distance migration (as opposed to the local county seat). Hence, family demographics are important in shaping general migration as well as migration destination, with seemingly larger impacts for long-distance migration. As longdistance migration means that the migrant cannot easily return if needed, these results are

\footnotetext{
${ }^{7}$ Mullan et al. (2011) show that migration is associated with an increased risk of land expropriation because land tenure arrangements in rural China involve administrative redistribution of some household lands to maintain egalitarian land holdings.
} 
fully consistent and stress the key importance of household demographics in shaping longdistance migration.

Interestingly, household human capital and assets play a differentiated role depending on destination. First, available per capita land lowers the probability of short-distance migration, but we do not find any significant impact on long-distance migration decision. Second, a higher educational level of the household head correlates positively with medium or short-distance migration, but correlates negatively with long-distance migration. This finding conforms to the ambiguous role of education in off-farm labour force participation in rural China found in the literature. In particular, there is evidence that better educated individuals tend to choose local off-farm work over migration (Zhao 2003).

Migration networks also play a prominent and differential role across long-distance and short-distance migration. Both community and family networks are at play in longdistance migration, whereas only the family network is found to significantly influence shortdistance migration. This result is consistent with the intuition that networks are a means to reduce migration costs. As long-distance migration usually involves higher costs and higher risks, migration networks at both the village and the family levels are unsurprisingly important drivers for such migration decisions.

Finally, we find interesting differences in the role played by locational characteristics of the sending community. A better access to market lowers the probability to send migrants to another province, while it increases the probability to send migrants to the local county seat. In remote places, the only available means to diversify income-generating activities is to send migrants to cities, possibly far away, whereas in better-connected villages, sending migrants a short-distance can be sufficient. Putting that another way, in better-connected villages there are more local opportunities for off-farm jobs. This is confirmed by the significantly higher incidence of long-distance migrants in central and western provinces and a significantly lower incidence of medium and short-distance migrants in central provinces (and to a lesser extent in western provinces).

The last two columns of Table 2 show recursive bivariate probit estimation results by migration duration (below or above 7 years). Here again, the determinants of the duration of migration differ substantially between short-term and long-term migration. As far as household characteristics and assets are concerned, we still find a positive and significant impact of household size and gender composition in facilitating migration decisions, for both short-term and long-term migration. Interestingly, the marginal effect of the household size is larger for short-term migration, whereas the marginal effect of the share of male adults is 
slightly larger for long-term migration. This may illustrate the fact that the male labour force is an important input for agricultural work. In this context, having enough male members to farm the land on a stable basis might be a prerequisite for sending migrants to cities for more than 7 years. Long-term migration decisions also depend more strongly on household land holdings: a larger land size significantly reduces the probability of a householdsending a migrant member for 7 years or more, whereas it does not significantly influence the decision to send a migrant for a short period. Again, this finding can be interpreted in terms of land tenure insecurity. As households may be concerned about potential administrative land reallocation, their incentive to send migrants for a long time may be lowered by the fear of losing their land.

Turning to the effect of migration networks, we find that both family migration experience and village migrant networks strongly increase the probability of a household sending a migrant for either a short or a long period of time. As an example, the probability of sending a migrant for less than 7 years is increased by 30 percent compared to households with no migration experience. Interestingly, the marginal effect of community networks is twice as strong for long-term migration.

\section{The level of migration}

To complement the above analysis on migration decisions, Table 3 presents the determinants of the number of migrating household members, again by destination and duration. Generally speaking, the factors that affect the number of migrating household members are similar to those that affect the household decision to send a migrant. Household characteristics and assets are found to be important drivers of the size of migration in a similar way as for the decision to migrate, and all our results regarding destination and duration choices hold with the number of migrant members.

\section{$<$ Insert Table 3>}

Besides expected similarities, one result deserves a specific comment. Indeed, we find an ambiguous effect of children on the size of migration: the number of children in the household is negatively correlated with the number of short-term migrants, but it is positively (and significantly) correlated with the number of long-term migrants in the household. Though the marginal effect is rather small, the positive correlation with long-term migration probably reflects the trade-off that Chinese rural households face. The institutional constraints imposed on rural households make the migration of a whole family very difficult, if not 
impossible. Indeed, land tenure arrangements induce rural households to keep some members in the countryside to protect their land use rights (Mullan et al. 2011), and the household registration system (Hukou) induces them to leave their children behind so that they can receive free primary and secondary education (Démurger and Xu 2011). Confronted by these strong institutional constraints, rural households with children may have higher incentives to send more family members to migrate for a longer period of time in order to cover the cost of the future education of their children. On the other hand, the presence of more children may lower the motivation to send household members in the short run because of potentially high psychological costs of separation.

Overall, the impact of migration networks is confirmed for the level of migration. The migration history of a household not only influences its propensity to send a migrant but it also increases the number of members sent to migrate. Likewise, if a village is sending a large share of migrants, families in this village are more likely to send more migrants than families living in villages with a smaller migration network. As for the migration decision, migration networks are found to be more important for long-distance rather than short-distance migration: the number of migrants sent to cities or to another province is positively related to both the family and the community network. In contrast, it is the family rather than the community network that counts for determining the number of members sent to migrate locally, and the family network's marginal effect is fairly small compared to the estimates for long-distance migration.

Finally, locational characteristics are found to influence the number of household members that migrate in a way similar to their impact on the likelihood to participate in migration. Rural households living in central or western provinces are more likely to send more migrants than households living in coastal provinces. As for destination and duration, they are also more likely to send more members farther from their home village, but for a shorter period of time as compared to households in coastal provinces.

\section{Conclusion}

This chapter aimed to unravel the main factors driving rural households in their decision to send family members to migrate. Migration was fairly widespread among households in rural China in 2007: about half of the sample households have at least one member working outside the village and for the sending households, the average number of migrant members is close to 1.7. We examined both the decision and the level of migration 
and highlighted a number of differences across destination choices as well as duration choices. Our key results can be summarized according to two main lines. First, differentiating migration decisions by distance and by duration emphasizes different modes of rural labour migration in China. Interestingly, household demographics and composition are found to be particularly constraining for long-distance as well as long-term migration. On the other hand, short-distance migration is negatively correlated to per capita household land, an additional $m u$ of land per capita reducing the probability of sending a member to the local county seat by 2 percentage points ${ }^{8}$. Household human capital, proxied by the number of years of education of the household head, reveals contrasting effects on migration that corroborate Zhao's (1999) findings for the mid-1990s that educated farmers prefer local non-farm work to migration. In our household-level estimates, education reduces long-distance migration whereas it increases short or medium-distance migration. Second, regarding migration networks, our results indicate that family and community networks do not play the same roles in facilitating migration, and in this sense may be thought of as complementary means of reducing costs for migrant candidates. While family migration networks uniformly influence migration, migration duration, migration destination as well as migration size, community networks appear to be less important for short-distance migration, which is relatively low cost and low risk, but very important for long-distance migration, which carries high levels of risk.

From a regional development perspective, our findings on the various modes of labour migration have a number of interesting implications. In her study of rural migrants at the end of the 1990s, Zhao (2003: 510) concluded that "with migrant networks, migration becomes a self-sustaining and self-enforcing process”. What our findings show is that this process has indeed been reinforcing over time and that it also shapes the extent of migration. With migrant networks, long-distance migration is facilitated, which contributes to the interprovincial redistribution of the population. Moreover, in inter-provincial flows, the effect of migrant networks goes beyond the family circle and community networks are found to play an active role. In addition to the self-enforcing process of migration through networks, our finding that a better access to local markets reduces migration also highlights another potentially important spatial issue. China is now experiencing a rapid rural labour exodus, a phenomenon that occurred in developed countries in the nineteenth and the twentieth centuries, which may lead to the deserting of remote rural areas. Our finding that people living in remote areas are more likely to migrate further away from their home village than

\footnotetext{
${ }^{8}$ Since the observed probability of short-distance migration is 18.9 per cent (Table 1), this effect is rather large.
} 
those living close to markets stresses the potential for such deserting. Hence, another key challenge to the central government for the coming years may be to find an efficient means of keeping remote areas alive and preventing a further agglomeration of people in a limited number of urban metropolises.

\section{References}

Barrett, C., Reardon, T. and Webb, P. 2001, 'Nonfarm income diversification and household livelihood strategies in rural Africa: Concepts, issues, and policy implications', Food Policy, vol. 26, no. 4, pp. 315-331.

Chen, Y., Jin, G. Z. and Yue, Y. 2010, 'Peer migration in China', NBER Working Paper, no. 15671.

Démurger, S. and Li, S. 2012, 'Migration, remittances and rural employment patterns: Evidence from China’, GATE Working Paper.

Démurger, S. and Xu, H. 2011, 'Left-behind children and return decisions of rural migrants in China’, GATE Working Paper No. 1122.

Dercon, S. and Krishnan, P. 1996, 'Income portfolios in rural Ethiopia and Tanzania: Choices and constraints', Journal of Development Studies, vol. 32, no. 6, pp. 850-875.

Görlich, D. and Trebesch, C. 2008, 'Seasonal migration and networks - Evidence on Moldova's labour exodus', Review of World Economics, vol. 144, no. 1, pp. 107-133.

Greene, W. H. 2008, Econometric analysis, 6th ed., NJ: Prentice Hall.

Hare, D. 1999, “"Push” versus “Pull” factors in migration outflows and returns: determinants of migration status and spell duration among China's rural population', Journal of Development Studies, vol. 35, no. 3, pp. 45-72.

Haug, S. 2008, 'Migration networks and migration decision-making', Journal of Ethnic and Migration Studies, vol. 34, no. 4, pp. 585-605.

Meng, X., Manning, C., Li, S. and Effendi, T. 2010, The Great Migration: Rural-Urban Migration in China and Indonesia, Edward Elgard, Cheltenham.

Mullan, K., Grosjean, P. and Kontoleon, A. 2011, 'Land tenure arrangements and rural-urban migration in China', World Development, vol. 39, no. 1, pp.123-133.

Rozelle, S., Guo, L., Shen, M., Hughart, A. and Giles, J., 1999, 'Leaving China's farms: survey results of new paths and remaining hurdles to rural migration', The China Quarterly, vol. 158, pp. 367-393.

Stark, O. 1991, The Migration of Labour, Blackwell, Cambridge and Oxford. 
Taylor, J. E., 1986, 'Differential migration, networks information and risk', in Migration, Human Capital and Development, ed. by O. Stark, Greenwich, Conn.: JAI Press.

Taylor, J. E., 1999, 'The New Economics of Labour Migration and the role of remittances in the migration process', International Migration, vol. 37, no. 1, pp. 63-88.

Todaro, M. 1969, 'A model of labor migration and urban unemployment in less developed countries' American Economic Review, vol. 59, no. 1, pp. 138-148.

Winters, P., de Janvry, A. and Sadoulet, E. 2001, 'Family and community networks in Mexico-U.S. migration', Journal of Human Resources, vol. 36, no. 1, pp. 159-184.

Zhao, Y. 1999, 'Labor migration and earnings differences: the case of rural China', Economic Development and Cultural Change, vol. 47, no. 4, pp. 767-82.

Zhao, Y. 2003, 'The role of migrant networks in labor migration: the case of China', Contemporary Economic Policy, vol. 21, no. 4, pp. 500-511.

Zhao, Z. 2005, 'Migration, labor market flexibility, and wage determination in China: a review', The Developing Economies, vol. 43, no. 2, pp. 285-312.

Zhu, N. 2002, 'The impacts of income gaps on migration decisions in China', China Economic Review, vol. 13, pp. 213-230. 
Table 1 - Summary statistics of sending and non-sending households

\begin{tabular}{|c|c|c|c|c|}
\hline & Total & $\begin{array}{c}\text { Non-sending } \\
\text { households }\end{array}$ & $\begin{array}{c}\text { Sending } \\
\text { households }\end{array}$ & Mean tes \\
\hline Percent of total number of households & 100 & 51.9 & 48.1 & \\
\hline Number of migrants per household & 0.81 & 0 & 1.68 & \\
\hline \multicolumn{5}{|l|}{$\begin{array}{l}\text { Percent of migrant-sending households } \\
\text { with a least one migrant member: }\end{array}$} \\
\hline - working in the local county seat & & & 18.9 & \\
\hline - working within the province & & & 29.6 & \\
\hline - working outside the province & & & 43.8 & \\
\hline - for less than 7 years & & & 60.4 & \\
\hline - for 7 years or more & & & 44.7 & \\
\hline \multicolumn{5}{|l|}{ Number of migrants per household: } \\
\hline - working in the local county seat & 0.34 & 0 & 0.70 & \\
\hline - working within the province & 0.22 & 0 & 0.46 & \\
\hline - working outside the province & 0.13 & 0 & 0.26 & \\
\hline - for less than 7 years & 0.43 & 0 & 0.89 & \\
\hline - for 7 years or more & 0.30 & 0 & 0.61 & \\
\hline \multicolumn{5}{|l|}{ Household characteristics and assets } \\
\hline Household size & 3.974 & 3.553 & 4.428 & $* * *$ \\
\hline Percent of adult males & 0.514 & 0.507 & 0.521 & $* * *$ \\
\hline \# old dependent & 0.176 & 0.198 & 0.154 & $* * *$ \\
\hline \# children below 16 & 0.666 & 0.639 & 0.695 & $* * *$ \\
\hline Age of household head & 50.33 & 50.32 & 50.33 & NS \\
\hline Years of education of household head & 7.190 & 7.184 & 7.197 & NS \\
\hline Per capita household land & 1.354 & 1.456 & 1.244 & $* * *$ \\
\hline \multicolumn{5}{|l|}{ Networks } \\
\hline Village share of migrants in 2005 & 0.167 & 0.142 & 0.194 & $* * *$ \\
\hline Family migration network & 0.303 & 0.0855 & 0.537 & $* * *$ \\
\hline \multicolumn{5}{|l|}{ Locational characteristics } \\
\hline Asphalt road in the village & 0.751 & 0.761 & 0.740 & $* *$ \\
\hline Central province & 0.362 & 0.331 & 0.397 & $* * *$ \\
\hline Western province & 0.200 & 0.171 & 0.231 & $* * *$ \\
\hline Sample size & 8,000 & 4,152 & 3,848 & \\
\hline
\end{tabular}

Source: RUMiC rural household survey 2007.

Notes: Family network is a dummy variable for households with more than one member with a migration experience. Some averages/percentages are calculated over a smaller number of observations because of missing values. We only report the total number of observations for reference. The mean test column indicates the significance level of mean differences between migrant-sending households and non migrant-sending households.

NS: non-significant. ${ }^{*}$ Significant at $10 \% .{ }^{* *}$ Significant at $5 \% .{ }^{* * *}$ Significant at $1 \%$. 
Table 2 - Probit and recursive bivariate probit estimates of migration decision

\begin{tabular}{|c|c|c|c|c|c|c|}
\hline & \multirow[t]{2}{*}{ Migration } & \multicolumn{3}{|c|}{ Destination } & \multicolumn{2}{|c|}{ Duration } \\
\hline & & $\begin{array}{l}\text { Another } \\
\text { province }\end{array}$ & City & Local & $\begin{array}{c}\text { Less than } 7 \\
\text { years }\end{array}$ & $\begin{array}{c}7 \text { years } \\
\text { and above }\end{array}$ \\
\hline \multicolumn{7}{|c|}{ Household characteristics and assets } \\
\hline Household size & $\begin{array}{l}0.133^{* * *} \\
(0.000)\end{array}$ & $\begin{array}{l}0.0388^{* * *} \\
(0.00491)\end{array}$ & $\begin{array}{l}0.0374^{* * *} \\
(0.00440)\end{array}$ & $\begin{array}{l}0.0129^{* * *} \\
(0.00402)\end{array}$ & $\begin{array}{l}0.0994^{* * *} \\
(0.00648)\end{array}$ & $\begin{array}{c}0.0137 \\
(.)\end{array}$ \\
\hline Percent of adult males & $\begin{array}{l}0.246^{* * *} \\
(0.000)\end{array}$ & $\begin{array}{l}0.0871^{* * *} \\
(0.0280)\end{array}$ & $\begin{array}{l}0.106^{* * *} \\
(0.0263)\end{array}$ & $\begin{array}{l}0.00546 \\
(0.0211)\end{array}$ & $\begin{array}{l}0.115^{* * *} \\
(0.0408)\end{array}$ & $\begin{array}{l}0.140^{* * *} \\
(0.0325)\end{array}$ \\
\hline \# old dependent & $\begin{array}{l}-0.115^{* * *} \\
(0.000)\end{array}$ & $\begin{array}{l}-0.0388^{* * *} \\
(0.00981)\end{array}$ & $\begin{array}{l}-0.0403^{* * *} \\
(0.00828)\end{array}$ & $\begin{array}{l}-0.0165^{* *} \\
(0.00722)\end{array}$ & $\begin{array}{l}-0.113^{* * *} \\
(0.0135)\end{array}$ & $\begin{array}{l}-0.00234 \\
(0.00957)\end{array}$ \\
\hline \# children below 16 & $\begin{array}{c}-0.115^{* * *} \\
(0.000)\end{array}$ & $\begin{array}{l}-0.0439^{* * *} \\
(0.00695)\end{array}$ & $\begin{array}{l}-0.0366^{* * *} \\
(0.00610)\end{array}$ & $\begin{array}{l}-0.0264^{* * *} \\
(0.00557)\end{array}$ & $\begin{array}{l}-0.170^{* * *} \\
(0.00986)\end{array}$ & $\begin{array}{c}0.0460 \\
(.)\end{array}$ \\
\hline Age of household head & $\begin{array}{c}-0.00253^{* * *} \\
(0.001)\end{array}$ & $\begin{array}{l}-0.00106^{* *} \\
(0.000512)\end{array}$ & $\begin{array}{l}-0.000001 \\
(0.000467)\end{array}$ & $\begin{array}{l}-0.000931^{* *} \\
(0.000390)\end{array}$ & $\begin{array}{l}-0.00461^{* * *} \\
(0.000644)\end{array}$ & $\begin{array}{l}0.00143 \\
\text { (.) }\end{array}$ \\
\hline $\begin{array}{l}\text { Years of education of } \\
\text { household head }\end{array}$ & $\begin{array}{c}0.00472^{*} \\
(0.081)\end{array}$ & $\begin{array}{c}-0.00467^{* * *} \\
(0.00166)\end{array}$ & $\begin{array}{l}0.00379^{* *} \\
(0.00157)\end{array}$ & $\begin{array}{l}0.00395^{* * *} \\
(0.00120)\end{array}$ & $\begin{array}{c}0.00260 \\
(0.00219)\end{array}$ & $\begin{array}{l}0.000354 \\
(0.00195)\end{array}$ \\
\hline $\begin{array}{l}\text { Per capita household } \\
\text { land }\end{array}$ & $\begin{array}{c}-0.0166^{* * *} \\
(0.009)\end{array}$ & $\begin{array}{l}-0.00533 \\
(0.00411)\end{array}$ & $\begin{array}{c}0.0000313 \\
(0.00290)\end{array}$ & $\begin{array}{l}-0.0201^{* * *} \\
(0.00518)\end{array}$ & $\begin{array}{c}0.00411 \\
(0.00385)\end{array}$ & $\begin{array}{l}-0.0225^{* * *} \\
(0.00548)\end{array}$ \\
\hline $\begin{array}{l}\text { Networks } \\
\text { Village share of } \\
\text { migrants in } 2005 \\
\text { Family migration } \\
\text { network }\end{array}$ & $\begin{array}{l}0.720^{* * *} \\
(0.000) \\
0.433^{* * *} \\
(0.000)\end{array}$ & $\begin{array}{l}0.359^{* * *} \\
(0.0666) \\
0.220^{* * *} \\
(0.0151)\end{array}$ & $\begin{array}{l}0.194^{* * *} \\
(0.0519) \\
0.164^{* * *} \\
(0.0141)\end{array}$ & $\begin{array}{l}-0.0683 \\
(0.0457) \\
0.0392^{* * *} \\
(0.0106)\end{array}$ & $\begin{array}{l}0.258^{* * *} \\
(0.0664) \\
0.346^{* * *} \\
(0.0151)\end{array}$ & $\begin{array}{l}0.508^{* * *} \\
(0.0663) \\
0.307^{* * *} \\
(0.0149)\end{array}$ \\
\hline \multicolumn{7}{|l|}{ Locational characteristics } \\
\hline $\begin{array}{l}\text { Asphalt road in the } \\
\text { village }\end{array}$ & $\begin{array}{l}0.0150 \\
(0.541)\end{array}$ & $\begin{array}{l}-0.0329^{* *} \\
(0.0153)\end{array}$ & $\begin{array}{l}0.0247^{* *} \\
(0.0124)\end{array}$ & $\begin{array}{l}0.0400^{* * *} \\
(0.0114)\end{array}$ & $\begin{array}{l}0.00132 \\
(0.0175)\end{array}$ & $\begin{array}{l}0.00781 \\
(0.0159)\end{array}$ \\
\hline Central province & $\begin{array}{l}0.0676^{* * *} \\
(0.003)\end{array}$ & $\begin{array}{l}0.311^{* * *} \\
(0.0214)\end{array}$ & $\begin{array}{l}-0.129^{* * *} \\
(0.0111)\end{array}$ & $\begin{array}{c}-0.0392^{* * *} \\
(0.0104)\end{array}$ & $\begin{array}{l}0.101^{* * *} \\
(0.0172)\end{array}$ & $\begin{array}{l}-0.00479 \\
(0.0161)\end{array}$ \\
\hline Western province & $\begin{array}{l}0.130^{* * *} \\
(0.000)\end{array}$ & $\begin{array}{l}0.237^{* * *} \\
(0.0307)\end{array}$ & $\begin{array}{c}-0.0423^{* * *} \\
(0.0127)\end{array}$ & $\begin{array}{l}0.00986 \\
(0.0162)\end{array}$ & $\begin{array}{l}0.0646^{* * *} \\
(0.0231)\end{array}$ & $\begin{array}{l}0.0706^{* * *} \\
(0.0222)\end{array}$ \\
\hline Sample size & 7,900 & 7,900 & 7,900 & 7,900 & 7,900 & 7,900 \\
\hline Log pseudolikelihood & $-4,109.5$ & $-6,211.7$ & $-6,180.0$ & $-5,801.2$ & $-6,376.3$ & $-6,449.5$ \\
\hline
\end{tabular}

Source: RUMiC rural household survey 2007.

Notes: see Table 1. A probit model is estimated for migration decision (column 1) and recursive bivariate probit models are estimated for migration destination and migration duration (columns 2 to 6). Marginal effects are reported in the table. They measure the change in the probability of sending migrant (total and by destination and duration) from a unit change in the explanatory variable. Robust standard errors are adjusted for clustering by villages (790 villages).

${ }^{*}$ Significant at $10 \%$. ${ }^{* *}$ Significant at 5\%. ${ }^{* * *}$ Significant at $1 \%$. 
Table 3 - Poisson estimates on the number of migrant members

\begin{tabular}{|c|c|c|c|c|c|c|}
\hline & \multirow[t]{2}{*}{ Total } & \multicolumn{3}{|c|}{ Destination } & \multicolumn{2}{|c|}{ Duration } \\
\hline & & $\begin{array}{l}\text { Another } \\
\text { province }\end{array}$ & City & Local & $\begin{array}{c}\text { Less than } 7 \\
\text { years }\end{array}$ & $\begin{array}{c}7 \text { years and } \\
\text { above }\end{array}$ \\
\hline \multicolumn{7}{|c|}{ Household characteristics and assets } \\
\hline Household size & $\begin{array}{c}0.173^{* * *} \\
(0.00679)\end{array}$ & $\begin{array}{l}0.0436 \\
(0.00345)\end{array}$ & $\begin{array}{l}0.0406^{* * *} \\
(0.00337)\end{array}$ & $\begin{array}{l}0.0232^{* * *} \\
(0.00507)\end{array}$ & $\begin{array}{l}0.0885^{* * *} \\
(0.00469)\end{array}$ & $\begin{array}{l}0.0256^{* * *} \\
(0.00394)\end{array}$ \\
\hline Percent of adult & $0.191^{* * *}$ & $0.0686^{* * *}$ & $0.0621^{* * *}$ & -0.0231 & 0.0488 & $0.110^{* * *}$ \\
\hline males & $(0.0417)$ & $(0.0211)$ & $(0.0239)$ & $(0.0306)$ & $(0.0302)$ & $(0.0289)$ \\
\hline \multirow[t]{2}{*}{ \# old dependent } & $-0.134^{* * *}$ & $-0.0353^{* * *}$ & $-0.0314^{* * *}$ & $-0.0206^{*}$ & $-0.105^{* * *}$ & 0.000653 \\
\hline & $(0.0157)$ & $(0.00827)$ & $(0.00759)$ & $(0.0107)$ & $(0.0123)$ & $(0.00784)$ \\
\hline \multirow[t]{2}{*}{ \# children below 16} & $-0.161^{* * *}$ & $-0.0386^{* * *}$ & $-0.0427^{* * *}$ & $-0.0315^{* * *}$ & $-0.147^{* * *}$ & $0.0210^{* * *}$ \\
\hline & $(0.00934)$ & $(0.00481)$ & $(0.00472)$ & $(0.00781)$ & $(0.00799)$ & $(0.00722)$ \\
\hline Age of household & $-0.00218^{* * *}$ & $-0.000626^{*}$ & 0.000448 & $-0.000953^{*}$ & $-0.00338^{* * *}$ & $0.00173^{* * *}$ \\
\hline head & $(0.000755)$ & $(0.000368)$ & $(0.000354)$ & $(0.000514)$ & $(0.000525)$ & $(0.000456)$ \\
\hline Years of education & 0.00182 & $-0.00385^{* * *}$ & $0.00278^{* *}$ & $0.00423^{* * *}$ & 0.00194 & -0.000721 \\
\hline of household head & $(0.00226)$ & $(0.00112)$ & $(0.00123)$ & $(0.00150)$ & $(0.00173)$ & $(0.00149)$ \\
\hline Per capita household & $-0.0261^{* * *}$ & -0.00337 & -0.00132 & $-0.0244^{* * *}$ & 0.00463 & $-0.0216^{* * *}$ \\
\hline land & $(0.00775)$ & $(0.00369)$ & $(0.00326)$ & $(0.00734)$ & $(0.00304)$ & $(0.00522)$ \\
\hline \multicolumn{7}{|l|}{ Networks } \\
\hline Village share of & $0.517^{* * *}$ & $0.202^{* * *}$ & $0.133^{* * *}$ & -0.0647 & $0.127^{* * *}$ & $0.335^{* * *}$ \\
\hline migrants in 2005 & $(0.0743)$ & $(0.0465)$ & $(0.0377)$ & $(0.0593)$ & $(0.0454)$ & $(0.0453)$ \\
\hline Family migration & $0.911^{* * *}$ & $0.309^{* * *}$ & $0.257^{* * *}$ & $0.0626^{* * *}$ & $0.557^{* * *}$ & $0.414^{* * *}$ \\
\hline network & $(0.0293)$ & $(0.0235)$ & $(0.0203)$ & $(0.0158)$ & $(0.0236)$ & $(0.0212)$ \\
\hline \multicolumn{7}{|c|}{ Locational characteristics } \\
\hline Asphalt road in the & 0.0147 & $-0.0263^{* *}$ & 0.0201 & $0.0501^{* * *}$ & -0.00463 & 0.00406 \\
\hline village & $(0.0198)$ & $(0.0108)$ & $(0.0124)$ & $(0.0153)$ & $(0.0144)$ & $(0.0119)$ \\
\hline \multirow[t]{2}{*}{ Central province } & $0.0611^{* * *}$ & $0.366^{* * *}$ & $-0.135^{* * *}$ & $-0.0623^{* * *}$ & $0.0695^{* * *}$ & 0.00216 \\
\hline & $(0.0200)$ & $(0.0300)$ & $(0.0104)$ & $(0.0133)$ & $(0.0136)$ & $(0.0127)$ \\
\hline \multirow[t]{2}{*}{ Western province } & $0.111^{* * *}$ & $0.319^{* * *}$ & $-0.0455^{* * *}$ & 0.0102 & $0.0428^{* *}$ & $0.0612^{* * *}$ \\
\hline & $(0.0288)$ & $(0.0458)$ & $(0.00995)$ & $(0.0207)$ & $(0.0203)$ & $(0.0173)$ \\
\hline Sample size & 7,900 & 7,900 & 7,900 & 7,900 & 7,900 & 7,900 \\
\hline $\log$ & $-7,490.9$ & $-4,432.9$ & $-3,665.3$ & $-3,049.3$ & $-5,337.9$ & $-4,422.1$ \\
\hline pseudolikelihood & & & & & & \\
\hline
\end{tabular}

Source: RUMiC rural household survey 2007.

Notes: see Table 1. Marginal effects are reported. Robust standard errors are adjusted for clustering by villages (790 villages).

${ }^{*}$ Significant at $10 \% .{ }^{* *}$ Significant at $5 \% .{ }^{* * *}$ Significant at $1 \%$. 